6. Mühlberger D, Wenkel M, Papapostolou G, et al (2020), "Surgical thrombectomy for iliofemoral deep vein thrombosis: Patient outcomes at 8.5 years". PLoS One, 15(6): e0235003. Published 2020 Jun 18. doi: 10.1371/journal.pone.0235003

7. Casey ET, Murad MH, Zumaeta-Garcia M, Elamin MB́, et al (2012), "Treatment of acute iliofemoral deep vein thrombosis". J Vasc Surg.,
55(5): 1463-73. doi: 10.1016/j.jvs.2011.12.082. Epub 2012 Mar 21. PMID: 22440631.

8. Protack CD, Bakken AM, Patel N, Saad WE, et al (2007), "Long-term outcomes of catheter directed thrombolysis for lower extremity deep venous thrombosis without prophylactic inferior vena cava filter placement". J Vasc Surg. 45(5): 992-7, discussion 997. doi: 10.1016/ j.jvs.2007.01.012. PMID: 17466791.

\title{
NGHIÊN CỨU VỀ TỔ HỢP GEN VKORC1 VÀ CYP2C9 TRÊN BÊNH NHÂN HUYẾT KHỐI TĨNH MACH NÃO ĐIỀU TRI WARFARIN
}

\author{
Nguyễn Hải Linh', Nguyễn Văn Liệu ${ }^{1}$, Nguyễn Thị Vân Anh²
}

\section{TÓM TẮT}

Acenocumarol là thuốc chống đông kháng vitamin $\mathrm{K}$ đường uống được sử dụng khá phổ biến. Thuốc có hiệu quả chống đông cao, giá thành rẻ nhưng giới hạn điểu trị hẹp và bị ảnh hưởng bởi các yếu tố như môi trường, di truyền. Các nghiên cứu trên thế giới đã chỉ ra rằng biến liều warfarin/ acenocumarol phụ thuộc rất lớn vào đa hình gen VKORC1 và CYP2C9. Sự xuất hiên của đa hình gen VKORC1 -1639G>A, CYP2C9*2, CYP2C9*3 làm tăng tính nhạy cảm với warfarin/ acenocumarol của cá thể. Nghiền cứu được thực hiện nhằm mục tiêu xác định mối liên quan giữa một số yếu tố lâm sàng và đa hình gen VKORC1 -1639G >A, CYP2C9*2, CYP2C9*3 và liều acenocumarol cần thiết ở bệnh nhân huyết khối tĩnh mạch não. Phương pháp: Xác định tỉ lệ đa hình gen VKORC1 -1639G>A, CYP2C9*2, CYP2C9*3 bằng phương pháp real-time PCR, từ đó đánh giá mối liên quan giữa một số yếu tố lâm sàng, cận lâm sàng và các kiếu gen này với liêu acenocumarol cân thiết. Kết quả: kiểu gen VKORC1 1639AA có tần số cao nhất chiếm tỉ lệ 78,1\%; sau đó là kiểu gen dị hợp-1639GA là 21,9\%. Trong đa hình gen CYP2C9, tî lệ kiểu gen đồng hợp kiểu dại CYP2C9*1/*1 là $96,9 \%$ vàCYP2C $9 * 1 / * 3$ là $3,1 \%$. Không phát hiện kiếu gen VKORC1 -1639GG và alen CYP2C9*2. Mối liên quan giữa yếu tố lâm sàng, kiểu gen VKORC1 và CYP2C9với liêuu acenocumarol cần thiết chưa thây khác biệt có ý nghĩa thống kê do cõ mẫu còn nhỏ và thời gian nghiên cứu cần kéo dài hơn.

Tư khóa: Acenocumarol, đa hình gen VKORC1 1639G >A, CYP2C9*2, CYP2C9*3.

\section{SUMMARY \\ INFLUENCE OF CLINICAL AND GENETIC FACTORS ON ACENOCUMAROL STABLE DOSE IN PATIENTS WITH CEREBRAL VENOUS THROMBOSIS}

\footnotetext{
${ }^{1}$ Trường Đai hoo Y Hà Nôi

Đại học Khoa học Tự nhiên, Đại học Quốc gia Hà Nội Chịu trách nhiệm chính: Nguyễn Hải Linh

Email: linhnh95@gmail.com

Ngày nhận bài: 2.4.2021

Ngày phản biện khoa học: 21.5.2021

Ngày duyệt bài: 3.6.2021
}

Acenocumarol, a widely-prescribed oral vitamin $\mathrm{K}$ antagonist drug, is a highly effective, low-cost anticoagulant, but with the narrow therapeutic index and large dose response variations. These variations are markedly influenced by genetic and non-genetic factors. Recently, studies have shown that acenocumarol doses are effected by genetic polymorphisms of VKORC1 and CYP2C9, enzymes being responsible for warfarin metabolism. Our study was conducted to determine the relationship between clinical characteristics and polymorphisms of VKORC1 -1639 G >A , CYP2C9*2, CYP2C9*3 with acenocumarol dose requirements. Method: Genotyping was performed to identify VKORC1 -1639G>A, CYP2C9 polymorphisms using real-time PCR and sequencing. Evaluation of these genotypes in relation to acenocumarol dose requirements. Result: VKORC1 1639AA was the most common genotype of VKORC1 allele among the study samples with a rate of $78.1 \%$, followed by VKORC1 $-1639 \mathrm{GA}$ at a rate of $21.9 \%$. In CYP2C9 variant, $96.9 \%$ and $3.1 \%$ of subjects carried CYP2C $2 * 1 / * 1$ and CYP2C $* 1 / * 3$, respectively. No detection of VKORC1 $1639 \mathrm{GG}$ and CYP2C9*2 allele. In addition, no statistically significant differences were found between clinical features, VKORC1, CYP2C9 polymorphism and acenocumarol stable dose in patients with cerebral venous thrombosis.

Keywords: acenocumarol, VKORC1 and CYP2C9 polymorphism, acenocumarol dose.

\section{I. ĐĂT VẤN ĐỀ}

Acenocumarol là thuốc chống đông kháng vitamin $\mathrm{K}$ đường uống được sử dụng khá phổ biến với ưu điểm như hiệu quả chống đông cao, giá thành rẻ. Tuy nhiên, thuốc lại có nhược điểm là giới hạn điều trị hẹp, bị ảnh hưởng bởi các yếu tố như môi trường, di truyền nên phải thường xuyên theo dõi các chỉ số đông máu như INR. Trên thực tế lâm sàng, có khi cần thời gian kéo dài hàng tuần đến hàng tháng sau khi khởi trị mới dò được liều ổn định và có sự khác biệt lớn về liều ổn định giữa các cá thể ${ }^{1}$. Một số nghiên cứu trên thể giới đã chứng minh sự ảnh hưởng của các yếu tố lâm sàng và di truyền như đa 
hình gen VKORC1 và CYP2C9 lên hiệu quả chống đông của acenocumarol/warfarin ${ }^{2}{ }^{3}$.

Gen VKORC1 mã hoá cho tiểu phần $\mathrm{C} 1$ của enzyme vitamin $\mathrm{K}$ epoxide reductase (VKOR), là enzyme đích của acenocumarol chịu trách nhiêm chuyển hoá vitamin $\mathrm{K}$ dạng oxy hoá thành dạng khử có hoạt tính, tham gia vào quá trình đông máu. Sư xuất hiến đa hình VKORC1 $-1639 \mathrm{G}>\mathrm{A}$ sẽ làm giảm hoạt động của enzyme này, do đó làm tăng hiệu quả chống đông và cầm giảm liều acenocumarol thấp hơn bình thường để đạt hiệu quả điều trị.

Gen CYP2C9 mã hoá enzyme CYP2C9 là môt enzyme thuộc hệ cytochrome P450, đóng vai trò quan trọng trong chuyển hoá acenocumarol. CYP2C9 có tính đa hình cao, trong đó đa hình CYP2C9*2 làm thay đổi acid amin Arg144Cys, CYP2C9*3 làm thay đổi acid amin Ile359Leu, đã được xác định là nguyên nhân gây giảm chuyển hoá acenocumarol ${ }^{4}$.

Hiện nay, y học cá thể hoá trong liệu pháp điều trị đang trở thành mối quan tâm lớn đối với các bác sĩ nhằm đưa ra liều điều trị tối ưu cho mỗi cá thể dựa trên đặc điểm di truyền của bệnh nhân, mang lại hiệu quả điều trị, đạt đích điều trị nhanh nhất, hạn chế các biến chứng. Vì vậy, nghiên cứu này được thực hiện nhằm mục tiêu xác định mối liên quan giữa một số yếu tố lâm sàng và đa hình gen VKORC1 $-1639 \mathrm{G}>\mathrm{A}$, CYP2C9*2, CYP2C9*3 và liều acenocumarol cần thiết ở bệnh nhân huyết khối tĩnh mạch não.

\section{II. ĐỐI TƯƠNG VÀ PHƯƠNG PHÁP NGHIÊN CỨU}

1. Đối tương. Gồm 32 bênh nhân được chẩn đoán huyết khối tĩnh mạch não điều trị thuốc chống đông kháng vitamin $\mathrm{K}$ acenocumarol (tên biệt dược: Sintrom 4mg).

Tiêu chuẩn lưa chon: Bênh nhân được chẩn đoán huyết khối tĩnh mạch não, điều trị acenocumarol từ 18 tuổi trở lền, đồng ý tham gia nghiên cứu.

Tiêu chuẩn loai trừ: Bênh nhân huyết khối tĩnh mạch não điều trị thuốc chống đông đường uống khác, phụ nữ có thai, bệnh lý về gan, thận đồng mắc.

\section{Phương pháp}

- Thiết kế nghiên cứu: Nghiên cứu mô tả cắt ngang kết hợp theo dõi dọc ngắn hạn.

- Thời gian thực hiện: Từ tháng 6/2020 đến tháng $6 / 2021$.

- Địa điểm: Khoa Thần kinh - Bệnh viện Bạch Mai và Phòng Thí nghiệm trọng điểm Công nghệ Enzyme và Protein, Đại học Khoa học Tự nhiên, Đại học Quốc gia Hà Nội.
- Các bước tiến hành:

- Lấy mẫu: Lấy 3ml máu tĩnh mạch ngoại vi của bệnh nhân tham gia nghiên cứu cho vào ống chứa chất chống đông EDTA, bảo quản ở nhiệt độ $-20^{\circ} \mathrm{C}$ cho đến khi phân tích.

- Tách chiết DNA từ máu ngoại vi: sử dụng bộ kit QIAamp DNA Mini Kit (Qiagen- Đức). Kiểm tra nồng độ và độ tinh sạch của DNA tách chiết bằng phương pháp đo quang, dựa vào tỉ lệ A260mm/A280mm = 1,8-2,0.

- Xác định kiểu gen của đa hình gen VKORC1 $-1639 G>A, C Y P 2 C 9 * 2$, CYP2C9*3 bằng kĩ thuật real-time PCR Taqman probe và giải trình tự gen để khẳng định chẩn đoán kiểu gen.Dựa trên trình tự genome của VKORC1 (Mã NG_011564.1) và CYP2C9 (Mã NG 008385.1) được khai thác tữ ngân hàng cơ sở dữ liệu của Trung tâm Thông tin Công nghệ Sinh học Quốc gia Hoa Kỳ (National Center for Biotechnology Information NCBI), sử dụng phầm mềm primer 5 kết hợp công cụ IDT Biophysics, primer và probe đặc hiệu cho kiểu gen SNP rs9923231 (VKORC1 1639G >A), SNP rs1799853 (CYP2C9*2-430C>T) và SNP rs1057910 (CYP2C9*3-1075A $>C)$. Thành phần phản ứng $\mathrm{PCR}$ : DW, TOPreal $2 X$ Reaction mix $2 X$, primer, probe.Chu trình nhiệt của phản ứng PCR: 1 chu kì với $95^{\circ} \mathrm{C}$ trong 10 phút để biến tính ban đầu, 45 chu kì ở $95^{\circ} \mathrm{C}$ trong 15 giây, gắn mồi kéo dài chuỗi ở $60^{\circ} \mathrm{C}$ trong 30 giây.Kết quả real-time PCR được chúng tôi đem đối chiếu với phương pháp PCR kết hợp với giải trình tự gen.

Sản phẩm PCR được điên di kiểm tra trên gel agarose 1,5\% sau đó tinh sạch để giải trình tự gen dịch vụ tại công ty $1^{\text {st }}$ Base (Singapore). Các kết quả trình tư được phân tích trên phần mềm BioEdit, ApE để xác định kiểu gen.

3. Xử lý số liệu. Phương pháp thống kê, kiểm định Chi bình phương và t-test trên phần mềm SPSS 20.0 để đánh giá tỉ lệ các alen, kiểu gen và mối liên quan giữa chúng với liều ổn định acenocumarol.

4. Đạo đức nghiên cứu. Nghiên cứu được thông qua bởi Hội đồng Đạo đức trường Đại học Y Hà Nôi. Các đối tượng tham gia nghiên cứu hoàn toàn tự nguyện và được giải thích đây đủ trước khi tham gia nghiên cứu. Các thông tin liên quan được đảm bảo bí mật.

\section{KẾT QUẢ NGHIÊN CỨU}

1. Đặc điểm chung của nhóm nghiên cứu. Tỉ lệ nam giới trong nhóm nghiên cứu là $43,8 \%$; nữ giới là $56,2 \%$.Tuổi trung bình của nhóm nghiên cứu là 40,72 $\pm 14,75$ tuổi. Bệnh 
nhân có độ tuổi thấp nhất là 18 tuổi, cao nhất 81 tuổi. Số liệu được trình bày trong Bảng 1.

Bảng 1. Đ̇ăc điểm lâm sàng của nhóm nghiên cứu ( $n=32$ )

\begin{tabular}{|c|c|c|c|}
\hline \multicolumn{2}{|l|}{ Thông số } & \multirow{2}{*}{$\begin{array}{l}\mathbf{n} \\
16 \\
\end{array}$} & \multirow{2}{*}{$\begin{array}{c}\text { Tỉ lệ \% } \\
50 \\
\end{array}$} \\
\hline Tuối & $\leq 40$ & & \\
\hline & $>40$ & 16 & 50 \\
\hline Giới & Nam & 14 & 43,8 \\
\hline & Nữ & 18 & 56,2 \\
\hline $\begin{array}{c}\text { Rối loạn tăng đông } \\
\text { nquyên phát }\end{array}$ & Có & 16 & 50 \\
\hline & Không & 16 & 50 \\
\hline Yếu tố nhiêm khuấn & Có & 9 & 28,1 \\
\hline & Không & 23 & 71,9 \\
\hline $\begin{array}{l}\text { Mang thai, sau đẻ hoăc } \\
\text { dùng thuốc tránh thai } \\
\text { đường uống (trong nhóm } \\
\text { hênh nhân nữ) }\end{array}$ & Có & 8 & 44,4 \\
\hline & Không & 10 & 55,6 \\
\hline
\end{tabular}

2. Đặc điểm di truyên của nhóm nghiên cứu $(n=32)$

Tỉ lệ kiểu gen đồng hợp đột biến VKORC1 $1639 \mathrm{AA}$ và dị hợp $-1639 \mathrm{GA}$ lần lượt là $78,1 \%$ và $21,9 \%$. Tần số alen đột biến -1639 A là $89,1 \%$. Tî lệ kiểu gen đồng hợp kiểu dại CYP2C9*2$430 C$ là $100 \%$. Tì lệ kiểu gen đồng hợpCYP2C9*3-1075AA và di hợp -1075AC lần lượt là $96,9 \%$ và $3,1 \%$. Khônng phát hiện đồng hợp kiểu dại VKORC1 -1639GG và alen CYP2C9*2trong nhóm bệnh nhân nghiên cứu. Số liệu được trình bày trong Bảng 2 .

Bảng 2. Đặc điểm di truyền của nhóm nghiên cứu ( $n=32$ )

\begin{tabular}{|c|c|c|c|}
\hline Thông số & $\mathbf{n}$ & Tỉ lệ \% \\
\hline \multirow{2}{*}{$\begin{array}{c}\text { Kiểu gen } \\
\text { VKORC1 }\end{array}$} & GG & 0 & 0 \\
\cline { 2 - 4 } & GA & 7 & 21,9 \\
\cline { 2 - 4 } & $\mathrm{AA}$ & 25 & 78,1 \\
\hline \multirow{2}{*}{$\begin{array}{c}\text { Kiểu gen } \\
\text { CYP2C9*2 }\end{array}$} & $\mathrm{CC}$ & 32 & 100 \\
\cline { 2 - 4 } & $\mathrm{CT}$ & 0 & 0 \\
\cline { 2 - 4 } & $\mathrm{TT}$ & 0 & 0 \\
\hline \multirow{2}{*}{$\begin{array}{c}\text { Kiểu gen } \\
\text { CYP2C9*3 }\end{array}$} & $\mathrm{AA}$ & 31 & 96,9 \\
\cline { 2 - 4 } & $\mathrm{AC}$ & 1 & 3,1 \\
\cline { 2 - 4 } & $\mathrm{CC}$ & 0 & 0 \\
\hline
\end{tabular}

3. Mối liên quan giữa một số đăcc điểm lâm sàng và liều acenocumarol ổn định

Trong số 32 bệnh nhân nghiên cứu, có 16 bệnh nhân đã xác định được lièu acenocumarol ổn định (liều ổn định là liều dùng mà INR 2 lần liên tiếp trong khoảng mục tiêu 2,0-3,0 và liều thuốc thay đổi không quá $20 \%$ trong 3 tháng liên tiếp ${ }^{5}$ ). Liều acenocumarol ổn định trung bình ở nhóm nghiên cứu là $1,73 \pm 0,39 \mathrm{mg} / \mathrm{ngày}$. Sự khác biệt giữa liều ổn định ở các nhóm tuổi (từ 40 tuổi trở xuống và trển 40 tuổi; giới tính; rối loạn tăng đông nguyên phát; có yếu tố mang thai, sau sinh, thuốc tránh thai đường uống) không có ý nghĩa thống kê. Số liệu được trình bày trong Bảng 3 .

Bảng 3. Mối liên quan giữa đặc điểm lâm sàng và liều ổn định $(n=16)$

\begin{tabular}{|c|c|c|c|}
\hline \multicolumn{2}{|c|}{ Thông số } & \multirow{2}{*}{$\begin{array}{c}\begin{array}{c}\text { Liều } \\
\text { (mg/ngày) }\end{array} \\
1,67 \pm 0,46\end{array}$} & \multirow{2}{*}{$\begin{array}{c}\begin{array}{c}\text { Giá trị } \\
\mathbf{p}\end{array} \\
0.445\end{array}$} \\
\hline Tuổi & $\leq 40(n=10)$ & & \\
\hline & $>40(n=6)$ & $1,83 \pm 0,26$ & \\
\hline Giới & $\operatorname{Nam}(n=7)$ & $1,63 \pm 0,39$ & 0,391 \\
\hline & Nữ $(n=9)$ & $1,81 \pm 0,40$ & \\
\hline \begin{tabular}{|c|} 
Rối loạn \\
tăng đống
\end{tabular} & Có $(n=6)$ & $1,93 \pm 0,46$ & 0,125 \\
\hline & Không(n=10) & $1,61 \pm 0,32$ & \\
\hline \begin{tabular}{|c|} 
Yếu tố \\
mang thai, \\
sau sinh, \\
thuốc tránh \\
thai đường \\
uống \\
\end{tabular} & Có $(n=3)$ & $1,95 \pm 0,58$ & 0,298 \\
\hline & Không(n=13) & $1,68 \pm 0,35$ & \\
\hline
\end{tabular}

4. Tỉ lệ kiểu gen VKORC1 -1639G >A, CYP2C9*2, CYP2C9*3 và mối liên quan với liều acenocumarol ổn định

Bảng 4. Ti lệ kiểu gen VKORC1 -1639G $>A$, CYP2C9*2, CYP2C9*3 và môi liên quan với liều acenocumarol ổn định ở nhóm nghiên cứu $(n=16)$

\begin{tabular}{|c|c|c|c|}
\hline $\begin{array}{l}\text { Kiếu } \\
\text { gen }\end{array}$ & n (\%) & $\begin{array}{c}\text { Liều } \\
\text { (mg/ngày) }\end{array}$ & $\begin{array}{c}\text { Giá trị } \\
\text { p }\end{array}$ \\
\hline \multicolumn{4}{|c|}{ VKORC1 -1639G >A } \\
\hline GG & $0(0 \%)$ & 0 & PGA-AA $=$ \\
\hline GA & $4(25 \%)$ & $1,89 \pm 0,61$ & 0,363 \\
\hline AA & $12(75 \%)$ & $1,68 \pm 0,31$ & \\
\hline \multicolumn{4}{|c|}{ CYP2C9 } \\
\hline$* 1 / * 1$ & $16(100 \%)$ & $1,73 \pm 0,39$ & \\
\hline$* 1 / * 3$ & $0(0 \%)$ & 0 & \\
\hline
\end{tabular}

Kiểu gen VKORC1 -1639AAvẫn chiếm đa sô trong nhóm 16 bệnh nhân, chiếm tỉ lệ $75 \%$, kiểu gen -1639GAchiểm tỉ lệ 25\%. 16 bệnh nhân đều có kiểu gen đồng hợp kiểu dại CYP2C9* $1 / * 1$. Không thấy sự khác biệt về liều ổn định giữa kiểu gen -1639AAvà -1639GA.

5. Kết quả xác định kiểu gen VKORC1 $1639 G>A$ và $C Y P 2 C 9 * 2$, CYP2C9*3 bằng kĩ thuật giải trình tự gen. Đoạn gen chứa các đa hình VKORC1 $-1639 \mathrm{G}>A$ và CYP2C9*2, CYP2C9*3 được khuếch đại bằng cặp mồi đặc hiệu. Sau khi kiểm tra, sản phẩm PCR được tinh sạch và giải trình tự, kết quả được minh hoạ ở Hình 1 và Hình 2.Sản phẩm real-time $P C R$ và giải trình tự gen rõ nét, các đỉnh màu tương ứng với các nucleotid rõ ràng, không có tín hiệu nhiễu. 

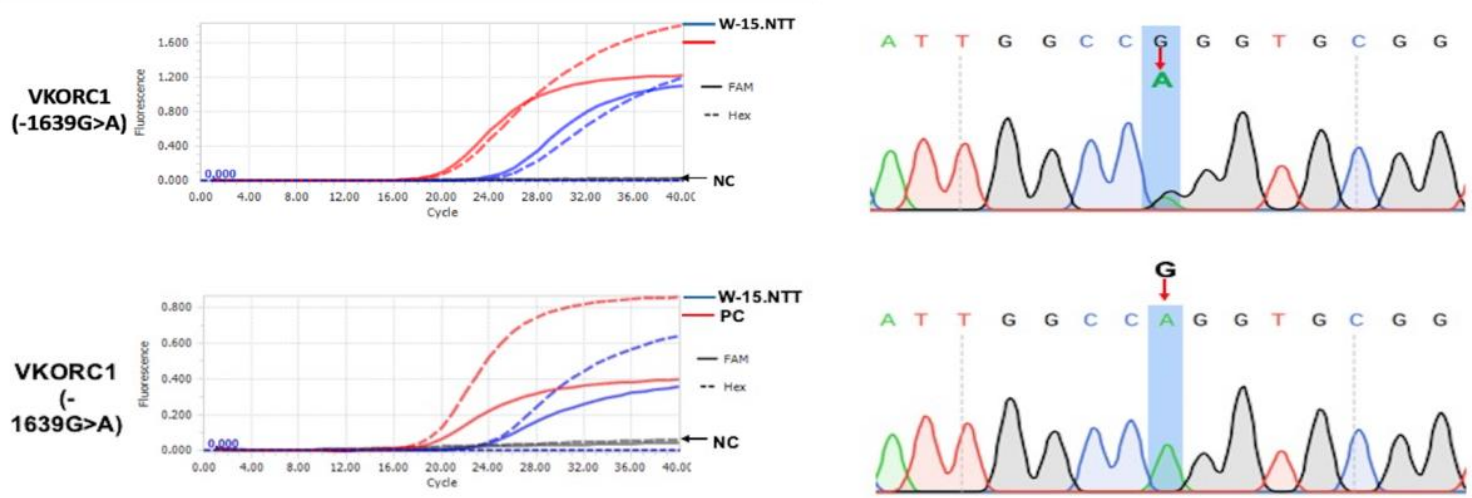

Hình 1. Hinh ảnh real-time $P C R$ và giải trình tứ gen của đa hình gen VKORC1 -1639G>A trong nghiên cứu (kiếu gen GA và $A A$ )
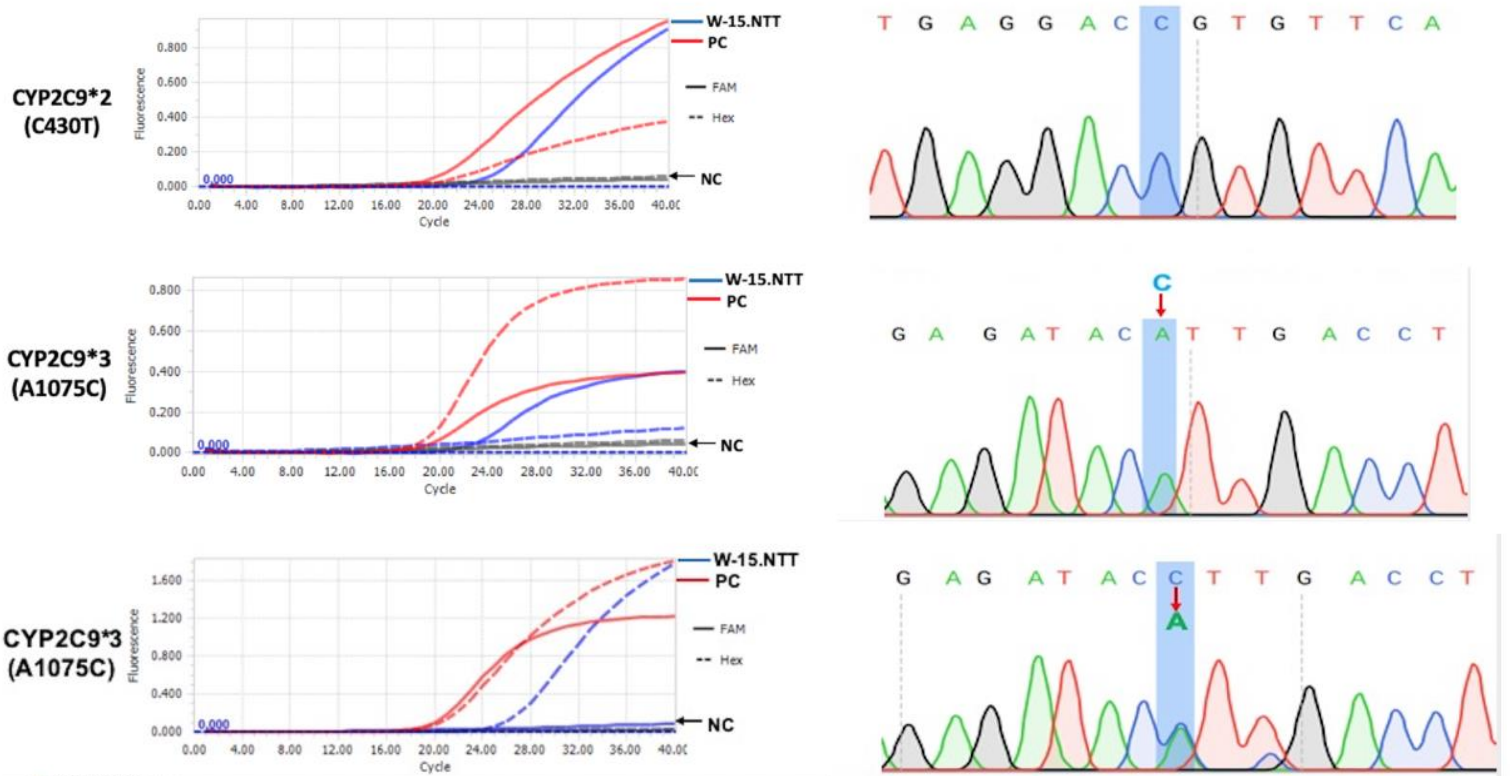

Hình 2. Hình ảnh real-time $P C R$ và giải trình tự gen của đa hình gen CYP2C9 trong nghiên cứu (kiêu gen CYP2C9*2 -430CC, CYP2C9*3-1075AA, -1075AC)

Chú thích: Nhóm bệnh nhân nghiên cứu của chúng tôi không ghi nhận được kiểu gen VKORC1 -1639GG và alen CYP2C9*2.

\section{BÀN LUẬN}

Nghiên cứu được tiến hành trên 32 bệnh nhân được chẩn đoán huyết khối tĩnh mạch não và điều trị bằng thuốc chống đông kháng vitamin $\mathrm{K}$ acenocumarol. Kết quả của chúng tôi cho thấy tuổi trung bình của nhóm nghiên cứu là 40,72 \pm 14,75 tuổi (dao động từ 18-81 tuổi)., trong đó $50 \%$ bệnh nhân có độ tuổi từ 40 trở xuống và $50 \%$ bệnh nhân trên 40 tuổi. Tỉ lệ nam giới trong nhóm bệnh nhân nghiên cứu chiếm 43,8\% và nữ giới chiếm $56,2 \%$. Trong số 18 bệnh nhân nữ giới, có 8 bệnh nhân (chiếm 44,4\%) được

chẩn đoán huyết khối tĩnh mạch não liên quan đến mang thai, sau sinh và dùng thuốc tránh thai đường uống. Bệnh nhân có rối loạn tăng đông nguyên phát (giảm protein $\mathrm{C}$, giảm protein $\mathrm{S}$, giảm antithrombin III) chiếm $50 \%$, có yếu tô nhiểm khuẩn chiếm $28,1 \%$ tổng số đối tượng nghiên cứu.

Trong 16 bênh nhân đã xác định được liều acenocumarol ổn định, liều trung bình của nhóm này là $1,73 \pm 0,39 \mathrm{mg} / \mathrm{ngày}$. Biến liều chống đông có thể do các yếu tố lâm sàng và di truyền ảnh hưởng tới liêu ổn định giữa các chủng tộc. Zhu, Caldwell đều chỉ ra yếu tố đa hình gen VKORC1 và CYP2C9 đóng vai trò rất lớn, trong đó kết hợp với một số yễu tố lâm sàng có thể giải thích được đến $56 \%$ biến liều ổn định của 
các cá thể ${ }^{2,3}$. Khi đánh giá mối liên quan giữa tuổi và liều acenocumarol cần thiết, Pop và cộng sự năm 2013 cho kết quả mối tương quan nghịch giữa tuổi và liều acenocumarol $(r=-$ 0,$339 ; \mathrm{p}<0,001$ ), điều này có thể lý giải do hoạt động của hệ thống enzyme cytochrome P450 giảm dần theo tuổi dẫn đến sự giảm chuyển hoá và đào thải thuốc ra khỏi cơ thể Tác giả Phạm Thị Thuỳ cũng ghi nhận kết quả tương tự với liều acenocumarol cần thiết ở nhóm trên 50 tuổi thấp hơn có ý nghĩa so với nhóm bệnh nhân dưới 50 tuổi $(1,61 \pm 0,58 \mathrm{mg} / \mathrm{ngày}$ so với $1,89 \pm 0,68 \mathrm{mg} / \mathrm{ngày})^{5}$. Tuy nhiên ở nghiên cứu của chúng tôi chưa tìm thây mối liên quan có ý nghĩa thống kê giữa liều acenocumarol ổn định với các yếu tố tuổi, giới, yễu tố nhiễm khuẩn, mang thai/sau sinh/ dùng thuốc tránh thai đường uống hay rối loạn tăng đông nguyên phát (do cỡ mẫu chỉ 16 bệnh nhân).

Bằng phương pháp real-time $\mathrm{PCR}$ và giải trình tự gen khẳng định chẩn đoán, chúng tôi thu được kết quả: với đa hình gen VKORC1 $1639 \mathrm{G}>\mathrm{A}$, kiểu gen đồng hợp đột biến (AA) và dị hợp (GA) chiếm tỉ lệ lần lượt là $78,1 \%$ và $21,9 \%$; không ghi nhận được kiểu gen đồng hợp kiêuu dại (GG). Tân số alen đột biến $A$ là $89,1 \%$ và alen $G$ là $10,9 \%$. Kết quả này tương đồng với quần thể châu Á trong một số nghiên cứu từ Nhật Bản, Trung Quốc, Malaysia, Indonesia với các bênh nhân dùng thuốc chống đông kháng vitamin K, cho thây tần số kiểu gen VKORC1 -1639AA dao động từ $66,5 \%$ đến $88 \%{ }^{7}$. Những bệnh nhân mang kiểu gen đồng hợp đột biến $A A$, dị hợp $G A$ có liều ổn định lần lượt là $1,68 \pm 0,31 \mathrm{mg} / \mathrm{ngày}$; $1,89 \pm 0,61 \mathrm{mg} / \mathrm{ngày}$; sự khác biệt về liều ổn định giữa hai kiểu gen không có ý nghĩa thống kề với $p>0,05$.Các nghiên cứu thế giới phần lớn cho kết quả kết quả đồng hợp đột biến $A A$ có liều acenocumarol ổn định tổi thiểu. Thậm chí VKORC1 -1639G>Alà alen chính (chiếm khoảng $90 \%$ ) ở cộng đồng người châu Á và đây có thể là một trong những yếu tố giải thích cho việc bệnh nhân châu Á hoăc gốc Á cần giảm liểu warfarin so với quần thể dân cư khác do sự xuất hiện của alen $A$ làm giảm chuyển hoá acenocumarol ${ }^{4}$.

Với đa hình gen CYP2C9, chúng tôi không ghi nhận được sự xuất hiện của alen CYP2C9*2, có 1 bệnh nhân có kiểu gen CYP2C9*1/*3 (đa hình gen CYP2C9*3 -1075A>Ccó kiểu gen dị hợp AC) - chiếm tỉ lệ rất thấp chỉ $3,1 \%$, trong khi ở kiểu gen đồng hợp kiểu dại CYP2C9*1/*1 chiếm đa số với tỉ lê $96,9 \%$. Tuy nhiên trong quá trình sử dụng thuốc chống đông, vào tháng thứ 2, bệnh nhân bị chấn thương sọ não gây tụ máu dưới màng cứng có chỉ định phẫu thuật mổ giải áp lấy máu tụ nên việc dùng chống đông phải dừng lại trong 6 tháng. Đến nay bệnh nhân vẫn chưa có chỉ định sử dụng lại thuốc chống đông để xác định liều acenocumarol ổn định. Tần số alen CYP2C9 có sự khác biệt giữa các chủng tộc khác nhau. Trong cộng đồng người gốc Âu, hai alen thường gặp nhất liên quan đến giảm hoạt động chuyển hoá của enzyme CYP2C9 là CYP2C9*2 $430 C>T$ và CYP2C $* 3-1075 \mathrm{~A}>\mathrm{C}$. Alen $* 2$ thường gặp nhất ở cộng đồng da trắng (10$20 \%$ ), hiểm hơn là cộng đồng người châu Phi. Khuyến cáo từ Hiệp hội Gen dược Warfarin đối với bệnh nhân mang ít nhất một alen CYP2C9*2 cần giảm liều warfarin ít nhất $17 \%$, cá thể mang ít nhất một alen CYP2C9*3 thì lại cần giảm liều ít nhất $37 \%$ so với liều dùng hàng ngày trung bình của những cá thể đồng hợp alen *14. Cục Quản lý Thực phẩm và Dược phẩm (FDA) năm 2017 đã một lần nữa nhấn mạnh tầm quan trọng của xét nghiệm định kiểu gen VKORC1 và CYP2C9 để ước tính liêuu thuốc chống đông kháng vitamin $\mathrm{K}$ ban đầu và liều ổn định trung bình.

Hạn chế trong nghiên cứu của chúng tôi là cõ mẫu còn nhỏ, thời gian theo dõi ngắn, một số bệnh nhân chưa xác định được liều ổn định do tuân thủ tái khám còn chưa tốt, bệnh nhân kém tuân thủ điều tri, ảnh hưởng của dich Covid-19. Do vậy việc phối hợp yếu tố lâm sàng, môi trường và di truyền để xác định liều chống đông tối ưu cho mỗi cá thể là rất cần thiết, nhất là trong điều kiện của Việt Nam khi việc tuân thủ tái khám và tiếp cận xét nghiệm còn hạn chế, để hạn chế biến chứng và đạt được hiệu quả điều trị hơn.

\section{KẾT LUẬN}

Nghiên cứu đã xác định được tỉ lệ kiểu gen VKORC1 -1639G>A, CYP2C9*2, CYP2C9*3 cũng như mối liên quan giữa các yếu tố lâm sàng, di truyền trên 32 bệnh nhân huyết khối tĩnh mạch não, và mối liên quan với liêu acenocumarol trên 16 bệnh nhân đã xác định được liều ổn định. Kiểu gen VKORC1 -1639AA có tần số cao nhất chiếm tỉ lệ $78,1 \%$; sau đó là kiểu gen dị hợp $1639 \mathrm{GA}$ là $21,9 \%$; tần số alen đột biến $\mathrm{A}$ là $89,1 \%$. Trong đa hình gen CYP2C9, tỉ lệ kiểu gen đồng hợp kiểu dại CYP2C $* 1 / * 1$ là $96,9 \%$ và CYP2C9*1/*3 là 3,1\%. Không phát hiện kiểu gen VKORC1 -1639GG và alen CYP2C9*2. Mối liên quan giữa yếu tố lâm sàng, kiểu gen VKORC1 và CYP2C9 với liều acenocumarol ổn định chưa có khác biệt có ý nghĩa thống kê do cõ̃ mẫu còn 
nhỏ và thời gian nghiên cứu cần kéo dài hơn, tuy nhiên bước đầu cũng đã xác định được kiểu gen bằng phương pháp real-time $P C R$, tỉ lệ kiểu gen và tần số alen, và mối liên quan có thể trên quần thể người Việt Nam.

\section{TÀI LIỆ THAM KHẢO}

1. Motulsky AG, Qi M. Pharmacogenetics, pharmacogenomics and ecogenetics. J Zhejiang $\begin{array}{lll} & \text { Univ Sci } \quad \text { B. } 2006 ; 7(2): 169-170 .\end{array}$ doi:10.1631/jzus.2006.B0169

2. Zhu $Y$, Shennan $M$, Reynolds $K K$, et al. Estimation of warfarin maintenance dose based on VKORC1 (-1639 G>A) and CYP2C9 genotypes. Clin Chem. 2007:53(7):1199-1205. doi:10.1373/clinchem.2006.078139

3. Caldwell MD, Berg RL, Zhang KQ, et al. Evaluation of Genetic Factors for Warfarin Dose Prediction. Clin Med Res. 2007;5(1):8-16. doi:10.3121/cmr.2007.724
4. Dean L. Warfarin Therapy and VKORC1 and CYP Genotype. In: Pratt VM, Scott SA Pirmohamed $M$, et al., eds. Medical Genetics Summaries. Bethesda (MD): National Center for Biotechnology Information (US); 2012. http://www.ncbi.nlm.nih.gov/books/NBK84174/. Accessed May 31, 2021.

5. Phạm Thi Thuỳ. Nghiên cứu tính đa hình gen CYP2C9, VKORC1 và liều thuốc chống đông kháng vitamin K ở bênh nhân thay van tim cơ hoc. 2021.

6. Pop TR, Vesa ŞC, Trifa AP, Crişan S, Buzoianu AD. An acenocoumarol dose algorithm based on a South-Eastern European population. Eur J Clin Pharmacol. doi:10.1007/s00228-013-1551-3

7. Qayyum A, Najmi MH, Mansoor $Q$, et al. Frequency of Common VKORC1 Polymorphisms and Their Impact on Warfarin Dose Requirement in Pakistani Population. Clin Appl Thromb Hemost. 2018;24(2):323-329.

doi:10.1177/1076029616680478

\section{NGHIÊN CỨU KẾT QUẢ SÀNG LOC PHÂN NHÓM NGUY CƠ CAO BÊNH LÝ TIỀN SẢN GIÂTT BẰNG THUÂT TOÁN FMF BAYES TẠI BÊ̂NH VIỆN QUỐC TẾ THÁI HÒA}

\section{TÓM TẮT}

Đặt vấn đề: Tiền sản giật (TSG) là một rối loạn đa hề thống gây ảnh hưởng $2 \%-5 \%$ thai kỳ̀, là bênh lý có nhiều biến chứng cho me và thai. Những ảnh hưởng này có thể đước thay đổi thông qua các mô hình dự báo và điêu trị dự phòng bệnh sớm giúp cải thiên kết cục thai kỳ. Mục tiêu nghiên cứu: Xác định tỷ lệ nhóm nguy cơ cao TSG theo thuật toán FMF Bayes của các thai phụ đến khám thai tại bệnh viện Quốc tế Thái Hòa và các yếu tố liên quan. Phương pháp nghiên cứu: Nghiên cứu cắt ngang trên 230 thai phu có tuổi thai 11 tuần đến 13 tuần 6 ngày đến khám thai tại bệnh viện Quốc tế Thái Hòa trong thời gian tháng 10/2020 đến tháng 4/2021. Tất cả các thai phụ đều được phỏng vấn, đo huyết áp động mach trung bình, đo Doppler đông mach tử cung trung bình và kết quá MoM PAPP-A. Dùng thuật FMF Bayes để tính nguy cơ TSG với ngưỡng cắt là $1 / 100$. Kết quả: Tỷ lệ nhóm nguy cơ cao TSG của các thai phụ đến khám thai tai bênh viên Quốc tế Thái Hòa là 11,6\%. Các yếu tố liên quan đến nhóm nguy cơ cao TSG có ý nghĩa thống kê như: Nhóm thai phụ có huyết áp tâm thu $>128 \mathrm{mmHg}$ (PR 7,4; KTC 95\%: 1,6-34,2) và

\footnotetext{
${ }^{1}$ Bệnh viện Quốc tế Thái Hòa

2Đai hoc Y Dươ TP.HCM

Chịu trách nhiếm chính: Võ Minh Tuấn

Email: vominhtuan@ump.edu.vn

Ngày nhận bài: 5.4.2021

Ngày phản biên khoa học: 26.5 .2021

Ngày duyệt bài: 8.6.2021
}

Huỳnh Thị Tuyết Mai ${ }^{1}$, Võ Minh Tuấn ${ }^{2}$ nhóm thai phụ có huyết áp tâm trương $>79 \mathrm{mmHg}$ (PR 8,5; KTC 95\%: 2,6- 28,4). Kết luân: Tâm soát nguy cơ tiền sản giật thường quy bằng thuật toán FMF Bayes cho tất cả thai phụ đến khám ở tuổi thai 11- 13 tuân 6 ngày, tư đó có kể hoach quản lý và điêuu trị dự phòng bằng aspirine liều thấp mỗi ngày sau tam cá nguyêt thứ nhất.

Tì̛ khóa: Tiền sản giật, Doppler động mạch tử cung, huyết áp trung bình.

\section{SUMMARY}

THE PREVALENCE OF SCREEN POSITIVE PRE-ECLAMPSIA AND ITS RISK FACTOR AT THAI HOA HOSPITAL

Background: Pre-eclampsia is a multisystem disorder affecting $2 \%-5 \%$ of pregnancies and is associated with multiple maternal and fetal complication. These effects an be altered through predictive models and early disease prevention, will improve pregnancy outcomes. Objective: to investigate the prevalence and relative factors of screen positive pre-eclampsia among pregnancies from Thai Hoa Hospital. Methods: Cross-section study of 230 pregnant women from 11 to 13 weeks 6 days of gestation who have antenatal care at Thai Hoa hospital, Đong Thap from October 2020 to April 2021. All pregnancies have measured value of mean arterial pressure, mean uterine artery PI and. serum PAPP-A was converted into MoM. Model-based estimates of screening performance using Bayes' theorem which the cut off points is $1 / 100$. Result: Survey of 230 samples has found that rate of screen positive pre- 